\title{
Effects of Prehospital Spinal Immobilization: A Systematic Review of Randomized Trials on Healthy Subjects
}

\author{
Irene Kwan, MSc; ${ }^{1}$ Frances Bunn, MSc $^{2}$
}

1. National Collaborating Centre for Women's and Children's Health, Royal College of Obstetricians and Gynecologists, London, England, UK

2. Centre for Research in Primary and Community Care, University of Hertfordshire, London, England, UK

Correspondence:

Irene Kwan

National Collaborating Centre for

Women's and Children's Health

Royal College of Obstetricians \&

Gynecologists

27 Sussex Place

Regent's Park

London NW1 4RG United Kingdom

E-mail: ikwan@rcog.org.uk

Funding by The National Health Service Research and Development Programme, United Kingdom

Keywords: healthy subjects; prehospital spinal immobilization; systematic review; trauma

\section{Abbreviations: \\ $\mathrm{SCI}=$ spinal cord injury}

Received: 18 May 2004

Accepted: 10 June 2004

Revised: 12 July 2004

Web publication: 22 December 2004

\begin{abstract}
Objective: To evaluate the effects of spinal immobilization on healthy participants.

Methods: A systematic review of randomized, controlled trials of spinal immobilization on healthy participants.

Results: Seventeen randomized, controlled trials compared different types of immobilization devices, including collars, backboards, splints, and body strapping. For immobilization efficacy, collars, spine boards, vacuum splints, and abdominal/torso strapping provided a significant reduction in spinal movement. Adverse effects of spinal immobilization included a significant increase in respiratory effort, skin ischemia, pain, and discomfort.

Conclusions: Data from this review provide the best available evidence to support the well-recognized efficacy and potential adverse effects of spinal immobilization. However, comparisons of different immobilization strategies on trauma victims must be considered in order to establish an evidence base for this practice.
\end{abstract}

Kwan I, Bunn F: Effects of prehospital spinal immobilization: A systematic review of randomized trials on healthy subjects. Prehosp Disast Med 2005;20(1):47-53.

Introduction

It is estimated that between 500-700 people in the United Kingdom and 10,000 people in the United States sustain a traumatic spinal cord injury each year. ${ }^{1,2}$ Spinal cord injury (SCI) predominantly affects males under the age of $50,{ }^{3}$ and results in long-term disability, often with profound effects on the quality of life of the affected individuals and their carers. About 36-48\% of acute traumatic SCI result from motor-vehicle collisions. ${ }^{4}$ Acute traumatic SCI occurs in about 3\% of trauma admissions to hospitals, and half of these injuries involve the cervical spine. ${ }^{3}$ In the United States, the average cost of traumatic $\mathrm{SCI}$ as a result of vehicle crashes is estimated to be approximately US $\$ 3.48$ billion per year. ${ }^{4}$

Prehospital spinal immobilization is one of the most frequently performed procedures for trauma patients in the field. It aims to stabilize the spine by restricting mobility, thus preventing exacerbation of spinal cord injury during extrication, resuscitation, transport, and evaluation of trauma patients with suspected spinal instability. One study concluded that $4.6 \%$ of trauma patients with cervical spine injuries had missed or delayed diagnoses, ${ }^{5}$ resulting in preventable mortality and morbidity. However, another study reported that the incidence of SCI without fracture was low $(0.7 \%)$, and the rate of missed cervical spine injury was even lower $(0.01 \%){ }^{6}$ Nevertheless, spinal immobilization is practiced routinely in the prehospital care of trauma patients, and is recommended in a range of resuscitation guidelines. ${ }^{7,8}$ 


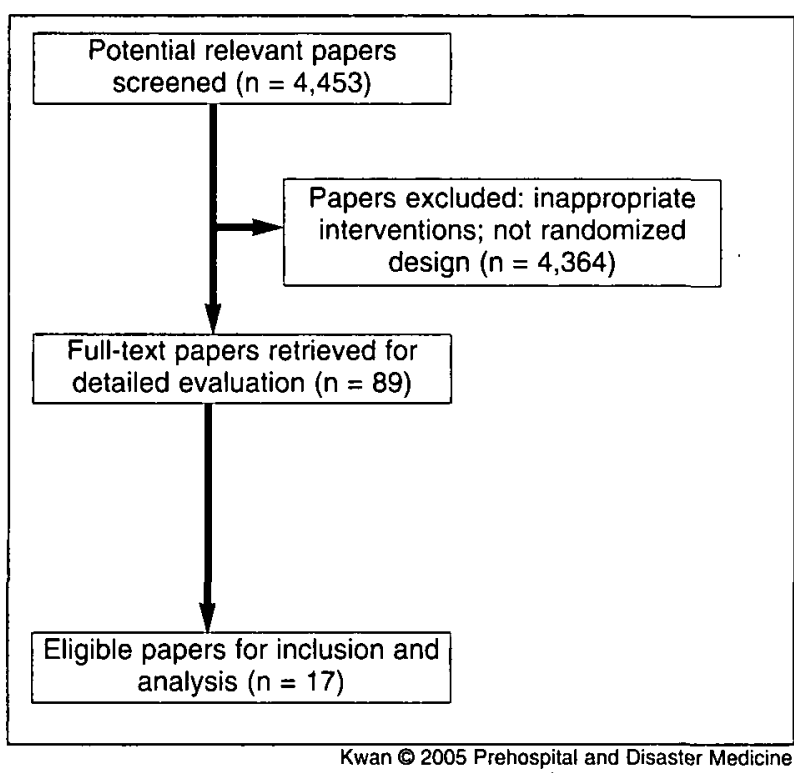

Figure $1-$ Summary of search results $(n=$ number $)$

Despite its widespread use, the clinical benefits of prehospital spinal immobilization have been questioned. It has been argued that spinal cord damage is done at the time of impact, and that subsequent movement generally is not sufficient to cause further damage. ${ }^{9}$ In a retrospective study comparing the effects of prehospital immobilization in two countries, non-immobilized patients were reported to have less neurological disability than did immobilized patients. ${ }^{9}$ Nevertheless, largely in response to the fear of litigation as a result of unrecognized occult fractures, approximately five million patients in the United States receive spinal immobilization every year. ${ }^{10}$

However, spinal immobilization is not a benign procedure. The adverse effects of spinal immobilization have been well-documented. Observational studies have shown that rigid collars may compromise the airway, increase intracranial pressure, ${ }^{11,12}$ augment the risk of aspiration associated with pulmonary restriction, ${ }^{13,14}$ cause dysphagia, ${ }^{15}$ and/or produce skin ulceration. ${ }^{16}$ In a recent systematic review, no randomized, controlled trials were identified that evaluate prehospital spinal immobilization in trauma patients. ${ }^{17}$ In the absence of appropriate trials on trauma patients, a systematic review was conducted to assess the effects of spinal immobilization on healthy subjects. The aim of this paper is to describe the results of this review and assess their relevance in light of the current understanding of the effects of spinal immobilization.

\section{Methods}

Selection criteria-All systematic reviews and randomized, controlled trials that assessed the effects of spinal immobilization in human subjects were included.

Identification of relevant studies - The biomedical databases MedLine, EMBASE (1966 to 2003), Cumulative Index to Nursing and Allied Health Literature (CINAHL)(1982 to 2003), and the Cochrane Central Register of Controlled
Trials (2003) were searched systematically for relevant trials. The search strategy has been described previously. ${ }^{17}$ The reference lists of all trials identified were searched for additional trials. Authors and manufacturers of immobilization devices were contacted for additional information. There was no language restriction in any of the searches.

Data extraction and study appraisal-One reviewer examined all electronic search results for reports of possibly relevant trials. To check for agreement, $10 \%$ of the records were double-screened. Potentially relevant reports then were retrieved in full. Data were abstracted on the method of randomization, allocation concealment, number of randomized participants, type of participants, interventions, and outcomes.

Since there is evidence that the quality of allocation concealment particularly affects the results of studies, ${ }^{18}$ this quality was scored independently by two reviewers as either "adequate", "unclear", or "inadequate". 18

Statistical methods-Due to differences in the types of interventions and outcomes assessed in the studies, a metaanalysis was not possible. Instead, the data are reported in tabular and narrative format.

Device order-The participants acted as their own control, and the order of the immobilization devices were randomized with "washout" periods inserted between the interventions. The types of immobilization devices assessed included: (1) collars; (2) backboards; (3) vacuum splint mattresses; (4) collars with backboards; (5) collars with air mattresses; (6) collars with vacuum splints; (7) collars with occipital padding; (8) abdominal strapping; and (9) towel rolls.

\section{Results}

The total number of potentially eligible records identified from the search strategy was 4,453 , of which 89 were retrieved. No trials that examined the effects of spinal immobilization on trauma patients were identified. However, 17 randomized, controlled, crossover trials comparing various types of spinal immobilization devices in 529 healthy volunteers, aged 7 to 85 years, were identified (Table 1 and Figure 1).

\section{Immobilization Efficacy}

Nine studies assessed immobilization efficacy as part of the outcome measures. ${ }^{19-27}$

Collars vs. no orthosis-There was evidence of effectiveness in significantly reducing cervical motion with a collar when compared with no collar $(p<0.05) .{ }^{19}$

Short board technique vs. collar-In two studies, a significant reduction in motion was reported with the short board technique when compared with collars $(p<0.05) .^{20,21}$

Backboard vs. vacuum splint with or without collar-One study reported a statistically significant increase in cervical immobilization with the vacuum splint plus cervical collar 


\begin{tabular}{|c|c|c|c|c|c|c|}
\hline Ref & Type of study & Participants & Intervention & Outcome measures & Resuts & $A C$ \\
\hline 29 & $\begin{array}{l}\text { RCT (Computer- } \\
\text { generated random } \\
\text { assignment; participants } \\
\text { acting as own control) } \\
\text { Unblinded }\end{array}$ & $\begin{array}{l}20 \text { healthy } \\
\text { volunteers } \\
\text { (Mean age } \\
27 \pm 9 \text { years) }\end{array}$ & $\begin{array}{l}\text { PC vs Aspen collar } \\
T T: 30 \mathrm{~min}, \text { WO: } 15 \mathrm{~min}\end{array}$ & $\begin{array}{l}\text { Occipital pressure by } \\
\text { digital skin pressure } \\
\text { evaluator; skin humidity } \\
\text { and temperature by digital } \\
\text { hygrometer }\end{array}$ & $\begin{array}{l}\text { No difference in occipital } \\
\text { pressure and skin } \\
\text { temperature between collars. } \\
\text { Increase in relative skin } \\
\text { humidity with PC }(\rho<0.001)\end{array}$ & A \\
\hline 30 & $\begin{array}{l}\text { RCT (Method of R NR; } \\
\text { participants acting as } \\
\text { own control) } \\
\text { Unblinded }\end{array}$ & $\begin{array}{l}37 \text { healthy } \\
\text { volunteers } \\
\text { (Age 17-49 } \\
\text { years) }\end{array}$ & $\begin{array}{l}\text { SNC + SB vs. SNC + } \\
\text { VMS } \\
\text { TT: } 30 \mathrm{~min}, \text { WO: } 2 \\
\text { weeks }\end{array}$ & Pain by 3-point LTS & \begin{tabular}{|l|} 
Subjects more likely to \\
complain of occipital and \\
lumbrosacral pain when \\
immobilized on a BB than on \\
a VMS $(p<0.001)$
\end{tabular} & B \\
\hline 20 & $\begin{array}{l}\text { RCT (method of R NR; } \\
\text { participants acting as } \\
\text { own control) } \\
\text { Observer blind }\end{array}$ & $\begin{array}{l}97 \text { healthy } \\
\text { volunteers } \\
\text { (Age 18-54 } \\
\text { years) }\end{array}$ & $\begin{array}{l}\text { PC vs. PC + SB vs. HEC } \\
\text { vs. HEC + SB vs. RPC } \\
\text { vs. RPC + SB vs. SB } \\
\text { only } \\
\text { TT and WO NR }\end{array}$ & $\begin{array}{l}\text { Immobilization efficacy } \\
\text { radiographically }\end{array}$ & $\begin{array}{l}\text { Reductioin in spinal mobility } \\
\text { with the SB technique } \\
(p<0.001)\end{array}$ & B \\
\hline 31 & $\begin{array}{l}\text { RCT (Method of R NR; } \\
\text { (participants acting as } \\
\text { own control) } \\
\text { Unblinded }\end{array}$ & $\begin{array}{l}20 \text { healthy } \\
\text { volunteers } \\
\text { (Age 16-50 } \\
\text { years) }\end{array}$ & $\begin{array}{l}\text { Collar + Spine board } \\
\text { with air mattress vs. } \\
\text { Collar + Spine board } \\
\text { without air mattress } \\
\text { TT: } 80 \text { min, WO: } 60 \text { min }\end{array}$ & $\begin{array}{l}\text { Pain by VAS; comfort by } \\
\text { 5-point LTS; contact } \\
\text { pressure by a pressure } \\
\text { evaluating device }\end{array}$ & $\begin{array}{l}\text { increase in pain and tissue- } \\
\text { interface pressures on spine } \\
\text { board without air mattress } \\
(p<0.05)\end{array}$ & B \\
\hline $\begin{array}{l}33 \\
(\mathrm{Ab})\end{array}$ & $\begin{array}{l}\text { RCT (Method of R NR; } \\
\text { participants acting as } \\
\text { own control) }\end{array}$ & $\begin{array}{l}12 \text { healthy } \\
\text { volunteers } \\
\text { (Age NR) }\end{array}$ & $\begin{array}{l}\text { Wooden BB vs. VMS } \\
\text { TT: } 2 \text { hours, WO NR }\end{array}$ & $\begin{array}{l}\text { Degree of discomfort by } \\
\text { VAS }\end{array}$ & $\begin{array}{l}\text { Less discomfort with VMS } \\
(p<0.05)\end{array}$ & B \\
\hline 21 & $\begin{array}{l}\text { RCT (Method of R NR; } \\
\text { participants acting as } \\
\text { own control) }\end{array}$ & $\begin{array}{l}45 \text { healthy } \\
\text { volunteers } \\
\text { (Age 18-61 } \\
\text { years) }\end{array}$ & $\begin{array}{l}\text { SNC vs. SBT; KED vs. } \\
\text { SBT; EPO vs. SBT } \\
\text { TT and WO NR }\end{array}$ & $\begin{array}{l}\text { Degree of immobilization } \\
\text { efficacy radiographically }\end{array}$ & $\begin{array}{l}\text { Increase in cervical } \\
\text { immobilization efficacy with } \\
\text { the SBT }(\rho<0.05) .10 \text { sets of } \\
\text { radiographs excluded }\end{array}$ & B \\
\hline 22 & $\begin{array}{l}\text { RCT (Method of R NR; } \\
\text { participants acting as } \\
\text { own control) }\end{array}$ & $\begin{array}{l}26 \text { adult } \\
\text { volunteers } \\
\text { (Mean age } \\
28.9 \pm 9.0 \\
\text { years) }\end{array}$ & $\begin{array}{l}\text { SNC + BB vs. BB vs. } \\
\text { SNC + VS vs. VS } \\
\text { TT: } 10 \mathrm{~min}, \text { WO NR }\end{array}$ & $\begin{array}{l}\text { Cervical range of motion } \\
\text { by an elecronic digital } \\
\text { inclinometer and hand- } \\
\text { held goniometer, and } \\
\text { VAS; comfort by } 10 \text {-point } \\
\text { LTS }\end{array}$ & $\begin{array}{l}\text { Increase in immobilization } \\
\text { efficacy and comfort with VS } \\
(p<0.05)\end{array}$ & B \\
\hline 35 & $\begin{array}{l}R C T \text { ( } R \text { using a table of } \\
\text { random digits; } \\
\text { participants acting as } \\
\text { own control) }\end{array}$ & $\begin{array}{l}22 \text { adult } \\
\text { volunteers } \\
\text { (Age NR) }\end{array}$ & \begin{tabular}{|l|} 
Traditional BB vs. BB \\
padded with a folded \\
blanket vs. BB padded \\
with a $3 \mathrm{~cm}$ gurney \\
mattress vs. BB and \\
mattress padded with a 6 \\
cm eggcrate foam pad \\
$\mathrm{TT}: 10$ min, wO: 15 min \\
\end{tabular} & $\begin{array}{l}\text { Ischemic pain and } \\
\text { comfort by VAS }\end{array}$ & $\begin{array}{l}\text { Increase in comfort with } \\
\text { padded BBs }(p<0.05)\end{array}$ & A \\
\hline $\begin{array}{c}34 \\
(A b)\end{array}$ & $\begin{array}{l}\text { RCT (Method of R NR; } \\
\text { participants acting as } \\
\text { own control) }\end{array}$ & \begin{tabular}{|l|}
57 adult \\
volunteers \\
(ages 65-75 \\
years)
\end{tabular} & $\begin{array}{l}\text { Full-length wooden BB } \\
\text { vs. VID } \\
\text { TT: } 30 \mathrm{~min}, \text { WO NR }\end{array}$ & $\begin{array}{l}\text { Ventilatory effort by } \\
\text { respiratory inductance } \\
\text { plethysmography and } \\
\text { VAS }\end{array}$ & $\begin{array}{l}\text { Increased respiratory effort } \\
\text { with BB }(p<0.05)\end{array}$ & B \\
\hline 23 & $\begin{array}{l}\text { RCT (Method of R NR; } \\
\text { participants acting as } \\
\text { own control) } \\
\text { Unblinded }\end{array}$ & $\begin{array}{l}30 \\
\text { paramedic } \\
\text { students } \\
\text { (Age NR) }\end{array}$ & $\begin{array}{l}\text { Collar + VS vs. Collar + } \\
\text { BB vs. VS only vs BB } \\
\text { only } \\
\text { TT: } 10 \mathrm{~min} \text {, WO NA }\end{array}$ & $\begin{array}{l}\text { Immobilization efficacy by } \\
\text { angles of tilting; } \\
\text { comfort by } 10 \text {-point LTS }\end{array}$ & \begin{tabular}{|l|} 
No difference in \\
immobilization efficacy \\
between VS and BB, with or \\
without collar. VS more \\
comfortable than BB \\
$(\rho<0.001) \quad$ continued \\
\end{tabular} & B \\
\hline
\end{tabular}

Kwan @ 2005 Prehospital and Disaster Medicine

Table 1-Effects of spinal immobilization on healthy participants $(\mathrm{A}=$ adequate; $\mathrm{Ab}=\mathrm{Abstract} ; \mathrm{AC}=$ Allocation concealment; $\mathrm{B}=$ unclear; $\mathrm{BB}=$ backboard $\mathrm{C}=$ inadequate; $\mathrm{CID}=$ Cervical immobilization device; $\mathrm{EPO}=$ Extrication plus-one; $\mathrm{HEC}=$ Hare extrication collar; $\mathrm{KED}=$ Kendrick extrication device; LTS = Likert-type scale; min = minutes; $\mathrm{NR}=$ not reported; $\mathrm{PC}=$ Philadelphia collar; $\mathrm{R}=$ randomization; $\mathrm{RCT}=$ randomized, controlled trial; $\mathrm{Ref}=$ reference number; $\mathrm{RPC}=$ rigid plastic collar; $\mathrm{SB}=$ short board; $\mathrm{SBT}=$ short board technique; $\mathrm{SNC}=$ StifNeck collar; $\mathrm{TT}=$ testing time (minutes); VAS $=10 \mathrm{~cm}$ visual analogue scale; VID = Vacuum immobilizer device; VMS = Vacuum mattress splint; VS = vacuum splint; $\mathrm{WO}=$ washout time (minutes)) 


\begin{tabular}{|c|c|c|c|c|c|c|}
\hline Ref & Type of study & Participants & Intervention & Outcome measures & Results & $\overline{\mathbf{A C}}$ \\
\hline 32 & $\begin{array}{l}\text { RCT (Method of R NR; } \\
\text { participants acting as } \\
\text { own control) } \\
\text { Unblinded }\end{array}$ & $\begin{array}{l}39 \text { healthy } \\
\text { volunteers } \\
\text { (Age 18-65 } \\
\text { years) }\end{array}$ & $\begin{array}{l}\text { Collar + BB with occipital } \\
\text { padding vs. Collar + BB } \\
\text { without occipital padding } \\
\text { TT: } 15 \text { min, then } 45 \text { min } \\
\text { lying supine; WO: } 2 \\
\text { weeks }\end{array}$ & $\begin{array}{l}\text { Incidence and severity of } \\
\text { pain by VAS }\end{array}$ & $\begin{array}{l}\text { No differences in incidence } \\
\text { and severity of pain between } \\
\text { immobilization with or } \\
\text { without occipital padding; } \\
\text { Pain reported by both } \\
\text { groups (range from } 69-73 \% \text { ) }\end{array}$ & $\mathrm{B}$ \\
\hline 19 & $\begin{array}{l}\text { RCT (Method of R NR; } \\
\text { participants acting as } \\
\text { own control) }\end{array}$ & $\begin{array}{l}10 \text { healthy } \\
\text { volunteers } \\
\text { (Age } 21-49 \\
\text { years) }\end{array}$ & $\begin{array}{l}\text { No collar vs. PC vs. } \\
\text { Miami J collar vs. Malibu } \\
\text { collar vs. Newport collar } \\
\text { TT and WO NR }\end{array}$ & $\begin{array}{l}\text { Degree of cervical motion } \\
\text { by video frames }\end{array}$ & $\begin{array}{l}\text { Reduced motion with each } \\
\text { orthosis than "no orthosis" } \\
(\rho<0.05) \text {; More restriction in } \\
\text { mobility with the Malibu col- } \\
\text { lar }(\rho<0.05)\end{array}$ & $B$ \\
\hline 26 & $\begin{array}{l}\text { RCT (Method of R NR; } \\
\text { participants acting as } \\
\text { own control) }\end{array}$ & $\begin{array}{l}20 \text { healthy } \\
\text { volunteers } \\
\text { (Age NR) }\end{array}$ & $\begin{array}{l}\text { Collar + corrugated } \\
\text { board CID strapped to } \\
\text { wooden board vs. (a) } \\
\text { Collar + reusable foam } \\
\text { board CID strapped to } \\
\text { wooden board; and (b) } \\
\text { Collar + rolled towel and } \\
\text { adhesive tape CID } \\
\text { strapped to wooden } \\
\text { board } \\
\text { TT and WO NR }\end{array}$ & $\begin{array}{l}\text { Motion restriction by } \\
\text { video frames; force } \\
\text { applied by participants } \\
\text { measured indirectly by } \\
\text { electromyography }\end{array}$ & $\begin{array}{l}\text { Motion restriction with a and } \\
\text { c compared with b }(p<0.05)\end{array}$ & $\mathrm{B}$ \\
\hline 27 & $\begin{array}{l}\text { RCT (Method of R NR; } \\
\text { participants acting as } \\
\text { own control) }\end{array}$ & $\begin{array}{l}19 \text { healthy } \\
\text { volunteers } \\
\text { (Age NR) }\end{array}$ & $\begin{array}{l}\text { BB with } 4 \text { torso strapping } \\
\text { techniques: } \\
\text { a. Standard style } \\
\text { b. Standard style + } \\
\text { abdominal straps } \\
\text { c. Standard style + } \\
\text { abdominal and chest/arm } \\
\text { straps } \\
\text { d. Standard style + } \\
\text { abdominal and chest/arm } \\
\text { straps without torso } \\
\text { cross straps } \\
\text { TT and WO NR } \\
\end{array}$ & $\begin{array}{l}\text { Reduction in lateral } \\
\text { motion by sliding } \\
\text { mechanism }\end{array}$ & $\begin{array}{l}\text { Reduced lateral motion wth } \\
\text { b, c, and d strapping } \\
\text { techniques (with abdominal } \\
\text { strap) when compared with a } \\
\text { (no abdominal strap) } \\
(p<0.05)\end{array}$ & $\mathrm{B}$ \\
\hline 24 & $\begin{array}{l}\text { RCT (Method of R NR; } \\
\text { participants acting as } \\
\text { own control) }\end{array}$ & \begin{tabular}{|l}
6 healthy \\
volunteers \\
(Age 22-28 \\
years)
\end{tabular} & $\begin{array}{l}\text { SNC + roller towel + } \\
\text { fracture board vs. SNC + } \\
\text { headbed + fracture } \\
\text { board vs. SNC + wedge } \\
+ \text { fracture board } \\
\text { TT: 8-14 min, WO NR }\end{array}$ & $\begin{array}{l}\text { Efficacy of head } \\
\text { immobilization by a } \\
\text { computer-controlled } \\
\text { moving platform }\end{array}$ & $\begin{array}{l}\text { No effect in eliminating head } \\
\text { movements with any of } \\
\text { these techniques }\end{array}$ & $\mathrm{B}$ \\
\hline \begin{tabular}{|l|}
28 \\
\end{tabular} & $\begin{array}{l}\text { RCT (Method of R NR; } \\
\text { participants acting as } \\
\text { own control) } \\
\text { Unblinded }\end{array}$ & $\begin{array}{l}39 \text { healthy } \\
\text { volunteers } \\
\text { (Age 7-85 } \\
\text { years) }\end{array}$ & $\begin{array}{l}\text { VC + vacuum mattress } \\
\text { vs. SNC + wooden board } \\
\text { TT and WO NR }\end{array}$ & $\begin{array}{l}\text { Ventilatory effects by } \\
\text { function tests and comfort } \\
\text { by 6-point LTS }\end{array}$ & \begin{tabular}{|l|} 
Ventilatory restriction with \\
whole-body spinal \\
immobilization compared \\
with baseline $(p<0.001) ;$ \\
Both wooden BBs and \\
vacuum mattresses \\
restricted respiration; \\
Vacuum mattresses more \\
comfortable than wooden BB \\
$(p<0.001)$
\end{tabular} & $\bar{B}$ \\
\hline 25 & $\begin{array}{l}\text { RCT (Method of R NR; } \\
\text { participants acting as } \\
\text { own control) } \\
\text { Unblinded }\end{array}$ & $\begin{array}{l}30 \text { healthy } \\
\text { volunteers } \\
\text { (Age 23-36 } \\
\text { years) }\end{array}$ & $\begin{array}{l}\text { Foam-padded spine } \\
\text { board vs. Unpadded } \\
\text { spine board } \\
\text { TT: } 30 \text { min, WO: } 14 \text { days }\end{array}$ & $\begin{array}{l}\text { Comfort by VAS; } \\
\text { immobilization efficacy by } \\
\text { bubble goniometer; sacral } \\
\text { tissue oxygenation by } \\
\text { transcutaneous oxygen } \\
\text { monitoring system }\end{array}$ & $\begin{array}{l}\text { Less discomfort with padded } \\
\text { spine board }(p=0.024) ; \text { No } \\
\text { difference in cervical range } \\
\text { of motion; No difference in } \\
\text { sacral tissue oxygenation }\end{array}$ & $\mathrm{B}$ \\
\hline
\end{tabular}

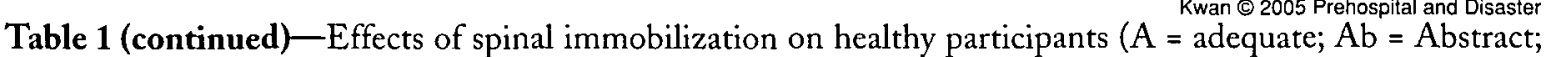
$\mathrm{AC}=$ Allocation concealment; $\mathrm{B}=$ unclear $; \mathrm{BB}=$ backboard $\mathrm{C}=$ inadequate; $\mathrm{CID}=$ Cervical immobilization device; $\mathrm{EPO}=$ Extrićation plus-one; $\mathrm{HEC}=$ Hare extrication collar; $\mathrm{KED}=$ Kendrick extrication device; LTS = Likert-type scale; $\min =$ minutes $; \mathrm{NR}=$ not reported $\mathrm{PC}=$ Philadelphia collar; $\mathrm{R}=$ randomization; $\mathrm{RCT}=$ randomized, controlled trial; $\mathrm{Ref}=$ reference number; $\mathrm{RPC}=$ rigid plastic collar; $\mathrm{SB}=$ short board; $\mathrm{SBT}=$ short board technique; $\mathrm{SNC}=$ StifNeck collar; TT $=$ testing time (minutes); VAS $=10 \mathrm{~cm}$ visual analogue scale; VC = vacuum collar; VID = Vacuum immobilizer device; VMS = Vacuum mattress splint; VS = vacuum splint; $\mathrm{WO}=$ washout time (minutes)) 
combination when compared with the backboard plus cervical collar combination $(p<0.05) .^{22}$ However, no statistically significant difference was found in immobilization measures between the backboard and the vacuum splint, with or without collar. ${ }^{23}$

Neck brace with rolled towels ws. headbed ws. styrofoam wedges - Substantial amounts of head and neck motion were reported regardless of whether rolled towels, headbed, or foam wedges were used. A comparison of these three devices showed no significant effect in reducing head and neck movements. ${ }^{24}$

Padded vs. unpadded spine board-Both padded and unpadded spine boards adequately immobilized the cervical 'range of motion. 25

Corrugated board vs. foam-board vs. towels with tapeCorrugated board and towels with tape were reported to provide statistically significantly more cervical motion restriction when compared with foam boards $(p<0.05){ }^{26}$

Body strapping-The addition of an abdominal strap to standard strapping technique was significantly associated with reduced lateral motion when compared with standard strapping technique with no abdominal strap $(p<0.05){ }^{27}$

\section{Adverse Effects}

Adverse effects of spine immobilization were reported in 11 trials. $^{22,23,25,28-35}$

Respiratory effects-Whole body immobilization either with a backboard or vacuum mattress and collar significantly restricted ventilation when compared with no immobilization $(p<0.001){ }^{28}$ For a group of older adult subjects, aged 65 to 75 years, significant increased ventilatory effort was reported with backboard when compared with vacuum immobilizer $(p<0.05) .{ }^{34}$

Skin ischemia and pain-The level of pain was assessed using instruments such as visual analogue scales. A mean occipital pressure of $>16-32 \mathrm{mmHg}$ was reported with immobilization between the Philadelphia collar and the Aspen collar. However, there was a significant increase in relative skin humidity with the Philadelphia collar when compared with the Aspen Collar $(p<0.001){ }^{29}$

Subjects immobilized with a collar and a standard backboard were significantly more likely to complain of pain when compared with immobilization on a vacuum mattress $(p<0.001) .{ }^{30}$ The use of collar and spine board without an air mattress was reported to result in a significant increase in pain and tissue-interface pressures when compared with collar and spine board with air mattress $(p<0.05) .{ }^{31}$ There was no significant decrease in the incidence or severity of pain between collar plus backboard with occipital padding and collar plus backboard without occipital padding. ${ }^{32}$ No significant difference in sacral tissue oxygenation was reported between the use of foam-padded spine boards and unpadded spine boards. ${ }^{25}$
Discomfort-The levels of comfort were assessed using visual analogue scales and the Likert-type scales. Significant improvements in comfort were associated with the use of vacuum mattress splints compared with wooden backboards $(p<0.05) .^{22,28,33}$ Significantly less discomfort was reported with foam-padded spine boards when compared with unpadded spine boards $(p<0.05) .{ }^{25,35}$

\section{Discussion}

In these trials on healthy participants, the devices compared were relatively effective for immobilizing the spine. However, there was evidence of adverse effects associated with these devices, such as increased ventilatory effort, ischemic pain, and discomfort.

The current protocol for prehospital spinal immobilization has a strong historical, rather than scientific, precedent based less on objective evidence, and more on the concern that a patient with an injured spine may deteriorate neurologically without immobilization. The medical and legal concern of missing a cervical spine injury has lent strong support for the conservative approach of liberal prehospital spinal immobilization to almost all patients with trauma and possible neck injury, regardless of clinical complaint. ${ }^{12}$ It has been suggested that iatrogenic cord damage could be reduced with better paramedic training and improved immobilization procedures. ${ }^{25}$ However, it also has been argued that considerable force is required to fracture the spine at the initial impact, and that any subsequent movements by routine handling and transport are unlikely to cause further damage to the spinal cord. ${ }^{9}$ Estimates in the literature regarding the incidence of neurological injury due to inadequate immobilization may have been exaggerated. 9,35

It is estimated that $>50 \%$ of trauma patients with no complaint of neck or back pain were transported with full spinal immobilization. ${ }^{36}$ Unwarranted spinal immobilization can expose patients to the risks of iatrogenic pain, skin ulceration, aspiration, and ventilatory compromise, resulting in multiple radiographs and unnecessary radiation exposure, longer hospital stays, and increased costs. The potential risks of aspiration and ventilatory compromise are of concern because death from asphyxiation is one of the major causes of preventable death in trauma patients. ${ }^{37}$ In addition, the studies described here suggest that spinal immobilization in patients with suspected spinal injury who are conscious, might reposition themselves to relieve the discomfort caused by ischemia. Theoretically, this repositioning could worsen any existing spinal injuries. Patients who are unable to move or feel pain due to trauma can be at risk for soft-tissue injuries. ${ }^{35}$

The Hoffman criteria, a set of highly-sensitive clinical criteria, have been developed and validated to identify trauma patients at low risk of spinal injury and rule out their need for radiography. ${ }^{38}$ Since its publication, a move among prehospital personnel has started to introduce spine clearance criteria. ${ }^{39-41}$ The proposed criteria would identify patients with spinal fractures by the presence of either: (1) altered mental status; (2) focal neurological deficit; (3) 
evidence of intoxication; (4) spinal pain or tenderness; or (5) a suspected extremity fracture proximal to the hand or foot. Identification and validation of these clearance criteria has been carried out, ${ }^{42-45}$ and evaluation of their use in the prehospital setting is needed. Criteria refinement, additional training of emergency medical services personnel, and development of quality assurance mechanisms are important considerations before implementation. The use of the proposed spine clearance criteria to identify trauma patients for selective immobilization would obviate the need for unwarranted spinal immobilization.

There are inherent methodological limitations of bias being introduced in studies in which participants acted as their own control and neither the participants nor the observers were blind to the interventions being assessed. It was not clear if the random order of the interventions was concealed during the trials to avoid potential selection bias by the investigators and performance bias by the participants. The duration of testing and "washout" periods varied in these trials. The difference in comfort or pain is anticipated to be more pronounced as the duration of immobilization increases. The subjective nature of pain and discomfort traditionally has made it problematic to assess the efficacy of many therapeutic techniques. The methods of measuring spinal range of motion with handheld goniometers versus other devices are likely to vary. This variability might explain the conflicting results of the immobilization efficacy of rolled towels and tape in two studies, ${ }^{24,26}$ one of which involved a small sample of only six subjects. ${ }^{24}$ It has been suggested that the subjective method of electromyography can be prone to intentional or unintentional variability by the participants, leading to inaccuracies ${ }^{26}$ Validation of these various measuring tools warrants consideration.

Two of the studies reviewed were abstracts and may not have been peer-reviewed. Due to the heterogeneous nature of the different immobilization devices used and outcomes measured, a meta-analysis combining all the study data was not performed. Although some of the immobilization devices assessed no longer were in use or not used widely at the time of the study, they still constituted the core instruments designed for the purpose of reducing spinal movement and exacerbation of spinal injuries.

Although unlikely, it is possible that important trials were missed using the extensive search strategy. This study systematically identified and reviewed the available empirical studies of randomized design that examined the effects of spinal immobilization on human subjects. Therefore, it provides a summary of the best available evidence, which firmly supports the well-recognized efficacy and adverse effects of spinal immobilization, depending on the techniques used. However, the fact that healthy participants with no spinal injuries were used in the trials described in this paper seriously limits the conclusions. The effects of spinal immobilization in trauma patients remains undetermined.

\section{Conclusion}

This systematic review supports the well-recognized understanding that spinal immobilization is associated with improved reduction in spinal mobility as well as adverse outcomes such as ventilatory restriction, ischemic pain, and discomfort. The widespread effort to establish the practice of selective immobilization during the prehospital phase is welcome. Randomized, controlled trials to compare different immobilization strategies on trauma patients need to be considered in order to establish an evidence base for the practice of prehospital spinal immobilization.

\section{Acknowledgements}

We thank Mr. R. Wentz for his help with the search, as well as the authors of background papers and manufacturers for supplying additional information.

\section{References}

1. Smith M: Making the Difference: Efficacy of Specialist Versus Non-Specialist Management of Spinal Cord Injury. London: Spinal Injuries Association, 1999.

2. McDonald JW, Sadowsky C: Spinal-cord injury. Lancet $2002 ; 359: 417-425$.

3. Burney RE, Maio RF, Maynard F, Karunas R: Incidence, characteristics, and outcomes of spinal cord injury at trauma centers in North America. Arch Surg 1993;128(5):596-599.

4. DeVivo MJ: Causes and costs of spinal cord injury in the United States. Spinal Cord 1997;35(12):809-813.

5. Davis JW, Phreaner DL, Hoyt DB, Mackersie RC: The etiology of missed spine injuries. J Trauma 1993;34(3):342-346.

6. Grossman MD, Reilly PM, Gillet T, Gillet D: National survey of the incidence of cervical spine injury and approach to cervical spine clearance in US trauma centers. J Trauma 1999;47(4):684-690.

7. Advanced Life Support Group. Advanced Paediatric Life Support, 1st edition. London: BMJ Publishing Group, 1993.

8. American College of Surgeons. Advanced Trauma Life Support Program for Dociors. 6th edition. Chicago: American College of Surgeons, 1997.

9. Hauswald M, Ong G, Tandberg D, Zahila O: Out-of-hospital spinal immobilization: Its effect on neurologic injury. Acad Emerg Med 1998;5(3): 214-219.

10. Orledge JD, Pepe PE: Out-of-hospital spinal immobilization: Is it really necessary? Acad Emerg Med 1998;5(3):203-204

11. Davies G, Deakin A, Wilson A: The effect of a rigid collar on intracranial pressure. Injury 1996;27(9):647-649

12. Butman A, Schelble DT, Vomacka RW: The relevance of the occult cervical spine controversy and mechanism of injury to prehospital protocols: A review of the issues and literature. Prebosp Disast Med 1996;11(3):228-233.

13. Bauer D, Kowalski R: Effects of spinal immobilization devices on pulmonary function in the healthy, non-smoking man. Ann Emerg Med 1988; 17(9):915-918.

14. Schafermeyer RW, Ribbeck BM, Gaskins J, et al: Respiratory effects of spinal immobilization in children. Ann Emerg Med 1991;20(9):1017-1019.

15. Houghton DJ, Curley JW: Dysphagia caused by a hard cervical collar. BrJ Neurosurg 1996;10(5):501-502.

16. Hewitt $\mathrm{S}$ : Skin necrosis caused by a semi-rigid cervical collar in a ventilated patient with multipie injuries. Injury 1994;25(5):323-324.

17. Kwan I, Bunn F, Roberts I: Spine Immobilization for Trauma Patients (Cochrane Review). In: The Cocbrane Library, Issue 3. Chichester, UK: John Wiley and Sons, Ltd., 2003.

18. Schulz KF, Chalmers I, Hayes RJ, Altman DG: Empirical evidence of bias. Dimensions of methodological quality associated with estimates of treatment effects in controlled trials. JAMA 1995;273(5):408-412.

19. Lunsford TR, Davidson M, Lunsford BR: The effectiveness of four contemporary cervical orthoses in restricting cervical motion. Joumal of Prosthetics and Orthotics 1994;6(4):93-99. 
20. Cline JR, Scheidel E, Bigsby EF: A comparison of methods of cervical immobilization used in patient extrication and transport. J Trauma 1985;25(7):649-653.

21. Graziano AF, Scheidel EA, Cline JR, Baer LJ: A radiographic comparison of prchospital cervical immobilization methods. Ann Emerg Med 1987; 16(10):1127-1131.

22. Hamilton RS, Pons PT: The efficacy and comfort of full-body vacuum splints for cervical-spine immobilization. J Emerg Med 1996;14(5):553-559.

23. Johnson DR, Hauswald M, Stockhoff CY: Comparison of a vacuum splint device to a rigid backboard for spinal immobilization. Am J Emerg Med 1996:14(4):369-372.

24. Perry SD, McLellan B, Mcllroy WE, et al: The efficacy of head immobilization techniques during simulated vehicle motion. Spine 1999;24(17): 1839-1844.

25. Walton R, DeSalva JF, Ernst AA, Shahane A: Padded vs. unpadded spine board for cervical spine immobilization. Acad Emerg Med 1995;2(8): 725-728

26. Manix T, Gunderson MR, Garth GC: Comparison of prehospital cervical immobilization devices using video and electromyography. Prehosp Disast Med 1995;10(4):232-238.

27. Mazolewski P, Manix TH: The effectiveness of strapping techniques in spinal immobilization. Ann Emerg Med 1994;23(6):1290-1296.

28. Totten VY, Sugarman DB: Respiratory effects of spinal immobilization. Prebosp Emerg Care 1999;3(4):347-352.

29. Black CA, Buderer NMF, Blaylock B, Hogan BJ: Comparative study of risk factors for skin breakdown with cervical orthotic devices: Philadelphia and Aspen. J Trauma Nurs 1998;5(3):62-66.

30. Chan D, Goldberg RM, Mason J, Chan L: Backboard versus mattress splint immobilization: A comparison of symptoms generated. $J$ Emerg Med 1996;14(3):293-298.

31. Cordell WH, Hollingsworth JC, Olinger ML, et at: Pain and tissue-interface pressures during spine-board immobilization. Ann Emerg Med 1995;26(1): 31-36.

32. Lerner EB, Billittier AJ, $4^{\text {th }}$, Moscati RM: The effects of neutral positioning with and without padding on spinal immobilization of healthy subjects. Prehosp Emerg Care 1998;2(2):112-116.
33. Delbridge TR, Auble TE, Garrison HG, Menegazzi JJ: Discomfort in healthy volunteers immobilized on wooden backboards and vacuum mattress splints. Prehosp Disast Med 1993;8(3 Supplement):S63. (Abstract).

34. Jedlicka DS: A comparison of the effects of no methods of spinal immobilization on respiratory effort in the older adult. Diss Abstra Int 1999;58-05B: 2354.

35. Hauswald M, Hsu M, Stockoff $\mathrm{C}$ : Maximising comfort and minimizing ischemia: A comparison of four methods of spinal immobilization. Prebosp Emerg Care 2000;4(3):250-252.

36. McHugh TP, Taylor JP: Unnecessary out-of-hospital use of full spinal immobilization. Acad Emerg Med 1998;5(3):278-280.

37. Hussain LM, Redmond AD: Are prehospital deaths from accidental injury preventable? Br Med J 1994;308(6936):1077-1080.

38. Hoffman JR, Mower WR, Wolfson AB, et al: Validity of a set of clinical criteria to rule out injury to the cervical spine in patients with blunt trauma. $N$ EnglJ Med 2000;343(2):94-99.

39. Domeier RM, Evans RW, Swor RA, et al: Prospective validation of out-ofhospital spinal clearance criteria: A preliminary report. Acad Emerg Med 1997;4(6):643-646.

40. Domeier RM, Evans RW, Swor RA, et al: Prehospital clinical findings associated with spinal injury. Prebosp Emerg Care 1997;1(1):11-15.

41. Domeier RM, Evans RW, Swor RA, et al: The reliability of prehospital clinical evaluation for potential spine injury is not affected by the mechanism of injury. Prebosp Emerg Care 1999;3(4):332-337.

42. Domeier RM: NAEMSP Position Paper: Indications for prehospital spinal immobilization. Prebosp Emerg Care 1999;3(4):251-253.

43. Domeier RM, Swor RA, Evans RW, et al: Multicenter prospective validation of prehospital clinical spinal clearance criteria. J Trauma 2002;53(4): 744-750.

44. Hankins DG, Rivera EJ, Ornato JP, et al: Spinal immobilization in the field: Clinical clearance criteria and implementation. Prebosp Emerg Care 2001;5(1):88-93.

45. Stroh G, Braude D: Can out-of-hospital cervical spine clearance protocol identify all patients with injuries? An argument for selective immobilization. Ann Emerg Med 2001;37(6):609-615. 